\title{
Teachers' and Students' Perceptions on Bullying Behaviour in Public Secondary Schools in Kisumu East District, Kisumu County, Kenya
}

\author{
Ochura Joseph Okoth \\ Master of Education in Guidance and Counselling: Educational Psychology, Maseno University, Kenya \\ Email: josephochura2000@yahoo.com
}

\section{Doi:10.5901/jesr.2014.v4n6p125}

\section{Abstract}

\begin{abstract}
World over, bullying subjects students to physical, social and psychological suffering. In Kenya, bullying in schools was illegalized and guidance and counselling programme put in place to manage the behaviour. The purpose of this study was to establish teachers' and students' perceptions on bullying among students in public secondary schools in Kisumu East District, since bullying escalated from 200 cases in 2006 to 900 cases in 2009. Objectives of the study were to establish bullying prevalence and identify types and forms of bullying among students. The study adopted descriptive survey design. Target population was students, deputy headteachers and heads of guidance and counselling from 47 schools. Stratified sampling was used to select 37 mixed, 5 boys' and 5 girls' schools. Saturated sampling was used to select 16 deputy headteachers and 16 guidance and counselling heads. A sample size of 447 students was used in the study as generated by the Creative Research System's formular (2003). Main tools for data collection were questionnaires and interview schedule. A pilot study of the instruments established reliability and coefficient indexes of 0.79 for students, 0.75 for deputy headteachers and 0.76 for guidance and counselling heads. Quantitative data was analyzed using descriptive statistics such as percentages. Qualitative data was transcribed, organized into themes and reported in text form. Findings of the study revealed that bullying was $31.1 \%$, $50 \%$ and $56.3 \%$ according to students, deputy headteachers and heads of $G$ and C; verbal type of bullying was the most common at $66.8 \%, 50 \%$ and $56.2 \%$. Most common forms of bullying were name-calling, group isolation and use of technological visual messages. The conclusion was that student bullying was still prevalent particularly in mixed gender schools and verbal bullying was the most common.
\end{abstract}

Keywords: bullying, perception, guidance and counselling.

\section{Introduction}

\subsection{Background of the Study}

World over, bullying of students is becoming more prevalent than ever before. It is also the most common form of aggression and violence in many schools that students engage in (Spiel, Salmivalli \& Smith, 2011). Studies in some European countries (Smith, 2011), in South Africa (Malematsa, 2005) and in Kenya (Ndetei, Ongecha, Khasakhala, Syanda, Mutiso, Othieno, Odhiambo \& Kokonya, 2007) show that bullying is not only common but also makes schools unsafe as perceived by learners, parents and educationists. Olweus, the pioneering researcher in bullying behaviour defined bullying as a long term exposure of the victim, to physical or verbal attack or social ostracism, intentionally perpetuated by a single or group of students (Olweus, 1993).

In the United States of America (USA), Unnever and Cornell (2004) in a survey to examine chronicity and type of bullying in six middle schools identified 898 out of 2,437 students who had been bullied yet $40 \%$ had not reported to anyone due to lack of concern. Batsche (2007) further established that in USA between 15 and 30 percent of the students are bullies or victims of bullying. In a Bangladeshi study, Ahmed (2005) found out that $30 \%$ of the students engaged in bullying someone at least once. The study further established that school intervention programmes to deal with the problem were non-existent, unlike in Kenya where for instance school guidance and counselling program exists. Statistics according to Daphine II Programme (2008) also show that bullying behaviour is estimated to bring misery to more than 1.5 million children in Britain, which is nearly 20 percent of the schools' population.

In Beijing, China prevalence and correlates of being bullied among adolescents in school was established to be 20 percent (23\% males and 17\% females) (Hazemba, Siziya, Muula \& Rudatsikira, 2008), while Lopes-Neto (2005) reported that data obtained from a survey in Brazil between 2002-2003 by the Brazilian Multi-professional Association for Child and Adolescent Protection (ABRAPIA) in elementary schools revealed that 40 percent of the students admitted that 
they were directly involved in bullying acts, with 80 percent of them expressing negative feelings of fear, pity, suicide and sadness due to the act. In Australia, bullying prevalence lies between 15 and 20 percent (Batsche, 2007) with reported cases of both bullies and bullying victims committing suicide or homicide (Morrison, 2002). In Korea a study in 2 middle schools among seventh and eighth grade students found out that $40 \%$ of respondents were involved in bullying with females and victims most likely to have suicidal tendencies respectively (Kim et al., 2005 in Poipoi, 2011).

In Africa, surveys with students and teachers show that 60 percent of students in Zambia reported being bullied at least once in one month (Jones, Moore, Villar-Marquez \& Broadbent, 2008). A study done in Free State Province, South Africa as reported by Okwemba (2007) also established a high prevalence of bullying behaviour in schools where 84 percent of the students and 95 percent of the teachers felt bullying was a big problem. In Botswana, a study by Moswela (2005) on peer victimization in 6 primary and 12 secondary schools established that student victimization occurred 100 percent. The study further found out that beating of boys and girls accounted for $21 \%$ and $9 \%$ respectively while namecalling of boys and girls was $15 \%$ and $22 \%$ respectively. In Nigeria, a study by Egbochuku (2007) as cited by Aluede (2011) of some students in Benin city revealed that almost 4 in every 5 participants (78\%) reported being bullied and $85 \%$ of the children admitted bullying others atleast once.

In Eastern Africa, Saito (2011) in assessing violence in primary schools between the years 2000-2007, established that Zanzibar island had the highest occurrence of all forms of bullying, for example, $73-98 \%$ of pupils used abusive language. In Tanzania, Ndibalema (2013) while exploring teachers' and students' perception about bullying behaviour among secondary schools in Dodoma Municipality, established that bullying persist in schools and that students are bullied by both their peers and teachers as well and cited an incident where a form four male secondary student aged 20 years was severely injured by his teacher. Still in Tanzania, Moris (2012) conducted a study in Dar-es-Salaam among secondary school students where it emerged that students were bullied by their teachers too and included humiliation, sexual harassment and corporal punishment. Students further reported high prevalent acts of gossiping at $74.3 \%$, spreading rumours at $70 \%$ and group exclusion at $70.2 \%$ among peers.

In Kenya, studies show that bullying has a long history as evidenced by increased violent cases in schools. According to Poipoi (2011) up to the late 1970s, it was a sort of compulsory disciplinary drill in most schools. In 1999 a group of male students in Nyeri High School locked up 4 prefects in their rooms at night for bullying them and doused them in petrol killing them instantly. In 2001 at a school in Bombolulu, 68 students were also burnt to death and many injured after their dormitory was set ablaze using petrol by two boys. According to Ikambili (2003), beating as a form of bullying accounted for about $30 \%$ in public mixed day secondary schools in Nairobi Province. The Government of Kenya (GoK) through the Ministry of Education (MoE) hence banned bullying acts in all schools in 2003 due to its violent nature that does not only result in death and permanent injuries among students but also due to its effects on learning (Ajowi, 2005). However, despite its ban bullying of students persists. In May 2006, a 15-year-old Form One student of a high school in Nyeri district in Central Province, further succumbed to injuries caused by a bully (Okwemba, 2007). Later in 2008, Mathiu (2008) reported that over 254 secondary schools in Kenya experienced violence with Central Province leading with 68 cases while Nyanza Province was third with 27 cases. The Minister for Education then, Professor Ongeri, cited bullying as one of the causes of the schools mayhem.

Research findings by Africa Mental Health Foundation (AMHF) (Ndetei, Ongecha, Khasakhala, Syanda, Mutiso, Othieno, Odhiambo \& Kokonya, 2007) further showed that students experience high levels of bullying of between 63 and 83 percent in public secondary schools in Nairobi Province. Ndetei et al., (2007) argue that this development does not only affect students' concentration in class and willingness to stay in school, but also jeopardizes their academic performance and self-esteem. In Bungoma district, Western Province, Simatwa (2007) found out that bullying was 100 percent experienced termly by victims as one of the school's infractions. In Nandi district, Rift-Valley Province, a study by Sang' (2007) revealed that high rate of school dropout both in primary and secondary schools occurred as a result of bullying activities. The most heinous bullying incidents recently reported in the Province were attempted circumcision of a male student in a local secondary school (Kandagor, 2008) and, senior students forcing a form one student to drink ethanol at Kituro secondary school in Baringo County which resulted in the affected boy being admitted to Kabarnet District Hospital in critical condition (Kiplagat, 2013). In Kangundo, Eastern Province, Daily Nation (2012) reported a bullying case in a public secondary school in which Form two students torched a dormitory in protest of their personal property being stolen by senior students.

Apart from being brutal, bullying behaviour also has social, physical and psychological effects on the victims (MacNeil, 2004). Learners who are bullied do not only consider school as unsafe but has also increased risk of depression and high rate of drug abuse (Ndetei et al., 2007). Bullying victims also tend to develop low self-esteem tendencies that progress into adulthood (Mutie \& Ndambuki, 2001). According to Mobegi (2007), bullying related 
incidents in schools further disrupt learning resulting in low academic performance both in class and national examinations such as Kenya Certificate of Secondary Education (KCSE).

In Nyanza Province, according to Affulo (2005) 67 percent of disciplinary problems experienced in secondary schools in Bondo district were bullying behaviour. Nyasato (2009) on the other hand reported a case where six prefects were expelled from a secondary school in Manga district, Kisii County, for brutally bullying form one students where one of the victims was seriously injured and admitted to the local district hospital. According to Ouma, Simatwa and Serem (2013) reports from Kisumu district's MoE's office in the province further indicated that bullying cases had escalated between 2006 and 2010 as follows: 2006 (200); 2007 (600); 2008 (800); 2009 (900) and 2010 (712). Bullying behaviour is therefore common in many schools in Kisumu East district and other parts of Kenya. The acts are often oppressive and persistent, sometimes continuing for weeks, months or even years in schools.

School administrators would want to dismiss the existence of bullying cases because of its seriousness and effects, but they still happen, Kiplagat (2008). It is on this account that guidance and counselling (G \& C) programme was recommended by $\mathrm{MoE}$ as a remedy to help address bullying behaviour and other discipline challenges in public secondary schools in Kenya. The Presidential Committee on Students" Unrest and Indiscipline in Public Secondary Schools (Republic of Kenya, 2001b) had attributed the problem of indiscipline in schools to a culture of violence and bullying, especially after MoE outlawed and banned corporal punishment in educational institutions as per legal notice No 56 of Kenya in the year 2001(Republic of Kenya, 2001) and through a circular Ref: G9/1/Vol.VIII/28 (MOEST, 2001).

\subsection{Literature Review}

Bullying is typically categorized as physical, verbal and relational (Malemesa, 2005). Due to modern technology in communication such as cell-phone, cyber-bullying has emerged as a new type / form of bullying. According to Jones, Moore, Villar-Marquez and Broadbent (2008), physical bullying includes behaviors such as hitting, kicking, or any form of overt violence towards a victim. It tends to receive more attention from school personnel over other forms of bullying. In Philippines, Jones et al., (2008) reported that a national study by World Health Organization (WHO) (2004) showed that over one-third of students who were bullied 30 days preceding the survey, 28\% reported being hit, kicked, pushed, shoved or locked indoors. Boys (35.8\%) were more likely than girls (22.2\%) to report such physical bullying. Malematsa (2005) in a South African case study concurred with WHO (2004) that physical bullying apart from involving intentional hitting and tripping up, also involved punching, damaging property, slapping, extortion, taking another learner's belongings and assault.

Simatwa (2007) in a study in Bungoma district, Western Province in Kenya, found out that public secondary schools experienced 100 percent physical attacks among male and female students per term. According to Ndetei et al., (2007), physical form of bullying is mainly common in boarding schools compared to day schools. This is after over 63 percent of students in secondary schools in Nairobi Province, Kenya, reported to have been beaten up or hit. Mwangi (2008) similarly reported that physical beating-regarded as a norm in some schools-turned tragic at a secondary school in Gilgil, Rift Valley Province, Kenya, when a Form Two boy lost his life due to physical injuries incurred after Form Four students had subjected him and his colleagues to a bullying ritual regarded as a 'rite of passage'. Statistics further indicated that a third $(1 / 3)$ of all forms of bullying involved physical violence and that some students were hospitalized after severe physical beatings (Nyasato, 2009).

Verbal bullying includes name-calling, threatening, insults and sarcasm whereas relational bullying entails gossiping, hostile gesturing, humiliation and ostracizing victims. According to Bohanon, Fenning, Carney, Minnis-Kim, Anderson-Harriss, Moroz, Hicks, Kasper, Culos, Sailor \& Pigott (2006), verbal bullying also involved teasing, mocking and taunting, for example, being called a teacher's 'pet'. Such abusive comments and insults are aimed at making fun, making one unhappy or feeling hurt. This type of bullying is common among girls than boys. Jacobsen \& Bauman (2007) in a survey on school counselors' response to three types of bullying incidences in schools in the USA established that $46.5 \%$ of all bullying is verbal type. In Austria, a study of 1,910 pupils from 86 classes in both primary and secondary schools established that prevalence of verbal bullying was high (between 4.4-26.4\%) compared to physical bullying (between 5.4-12.8\%) (Spiel \& Strohmeier, 2011).

In Kisii district, Nyanza Province, Kenya, Onditi (2007) established that pupils in primary schools in Suneka Division rated name-calling by teachers at $62.4 \%$. This contributed to school dropout which affected girls more than boys. Okwemba (2007) also reported $71 \%$ of the students reported to have been called nasty names, $68 \%$ had tricks played on them and 64\% had been blackmailed in seventeen public secondary schools in Nairobi Province. Malematsa (2005) argued that verbal type of bullying is difficult to deal with because the bullies usually deny having done it and lack of 
tangible evidence from witnesses.

Relational bullying mostly occurs when victims are excluded from a group of peers or friends, or isolated in play and work activities. According to Batsche (2007), relational bullying entails using personal relationship to harm someone. It is reputational in nature in that it harms someone's social status in class or school. Like physical and verbal bullying types, Malematsa (2005) argues that relationship bullying includes spreading rumours, ignoring someone, telling and/or passing notes which contain cruel statements about an individual. Other activities are gossiping, intimidating and scaring someone by staring and hiding one's belongings or property.

In Florida, USA, the second annual bullying prevention conference in April, 2007, observed that just as males were more likely to use physical and verbal aggression than females, the latter were also better than males in relational bullying (Batsche, 2007). Hazemba, Siziya, Muula \& Rudatsikira (2008) reported that in a sample of 692 Turkish high school students, $28.3 \%$ reported having been bullied emotionally, at least once during an academic year.

Researchers further argued that relational type of aggression is rated by children to be more painful than even physical aggression (Low, Frey \& Brockman, 2010). Simatwa (2007) also established that telling lies in school in Bungoma District, Kenya, was as high as $100 \%$ among students. This behaviour is more prevalent amongst female students of Forms Two and Three (Ndetei et al., 2007). Ndetei et al., (2007) further argues that girls value social relationships more than boys hence those who are bullies set out to disrupt social relationships of the girls they are bullying, for instance, telling lies or spreading rumours about them using new technologies such as cell-phones. A study by Poipoi, Agak and Kabuka (2011) on perceived home factors contributing to violent behaviour among students in public secondary schools in Western Province, Kenya, further indicated that gossiping in school was reported by $63.8 \%$ of male teachers, $63.9 \%$ by female teachers and $73.5 \%$ by students. Hiding or taking of fellow students belonging is similarly a major problem in secondary schools in Kenya. A recent report shows that Form Two students in a secondary school in Kangundo went on rampage in protest of their personal belongings being stolen by senior students (Daily Nation, 2012).

According to Oliver \& Candappa (2003) bullying by electronic communication such as text messaging and e-mail have been included among the various mechanisms through which bullying may be perpetuated using modern technology. Technological bullying also known as digital or cyber bullying is a new and insidious type of bullying that has emerged in different parts of the world (Anonymous, 2003a). It involves deliberate sending of menacing text messages via e-mail, cell phones and computers by an individual or a group of persons which are intended to harm others. Thomas and McGee (2012) add that cyber bullying is using technology such as the internet or cell phone to deliberately insult, threaten or intimidate someone for example, through mean text. Just like the traditional bullying, this type of bullying is about power and often times aims at gaining social status. According to Nelson (2003), cyber bullying is often more serious than traditional bullying and it includes stalking and death threats. He argues that youths do also create hatefilled Web pages and cell phone Short Message Service (SMS) about a victim, including personal information which is extraordinarily damaging to the person who is being victimized by it.

In America, a study by the Pew Internet and American Life Project found out that $26 \%$ of teens had been harassed through their mobile phones either by calls or text messages (Lenhart et al., 2011 cited by Thomas and McGee, 2012). Further in USA, statistics from the Alliance of Childhood Bullies and Victims showed that girls were twice as likely as boys to be victims and perpetrators of digital bullying (AMA Alliance, 2007). In the United Kingdom (UK), Hayes, an education correspondent reported a survey carried out with adolescents, which indicated that $14 \%$ to $23 \%$ admitted having sent offensive, pornographic, abusive or threatening texts using cell phones (Hayes, 2008). This situation led to a national public outcry demanding banning of mobile phones to curb bullying in schools. Cyber bullying also involve the practice of sexting (sending sex-related text or photograph). According to National Campaign to Prevent Teen and Unplanned Pregnancy in USA, 1 in 5 teens reported sending a nude or semi-nude photo of themselves to someone in a text message. Further $22 \%$ of the teens reported having received such messages from someone else (Thomas and McGee, 2012). As a result of this sexting problem, studies show some teenager students harassed by cyber bullying suffered depression, had their education compromised, while some committed suicide (Shariff, 2008).

In Australia, a study by Cross, Epstein, Hearn, Slee, Shaw \& Monks (2011) in a national covert bullying survey in Australian government primary and secondary schools established that female students (7.7\%) engaged more in cyber I technological bullying than male students (5.2\%). Patchin and Hinduja (2009) studied 1,500 adolescents and found that $33 \%$ of the respondents were victims of cyber bullying. In China, a survey in February 2007 of 832 teenagers by the National Crime Prevention Council reported that $43 \%$ of teens aged between 13-17 years had experienced cyber bullying (Moessner, 2007). According to Shariff (2008), technology allows information to reach a large number of people in a short period of time and the speed of technology can spread rumors and humiliating pictures faster and to more people than word of mouth. Additionally, everyone receives the same message when technology is used instead of word of 
mouth and the rumors can stay on the Internet or cell phone indefinitely.

In Kenya, MoE has banned possession and use of mobile phones in public schools which was blamed for spreading cheap rumours that spread damage in schools during rampant unrests (Opondo, 2008). However, few still get their way into schools and may be used for bullying. This was confirmed by the headteacher of Kioge Girls' School, Nyanza Province, who lamented that with the advent of mobile phones, other forms of behaviour such as bullying have surfaced (Mwajefa \& Marete, 2008). Indeed, cell phone and online incidents that occur away from school can trigger in school behavior such as school violence. Students may come to school angry as a result of conflicts that occurred through online communication since a student may not know what was said about him or her online until he or she hears about it the next day at school. Beran \& Li (2007) argued that a student who is being bullied at school may also become an online bully to retaliate against the bully at school. Being upset about a cyber bullying incident while in school can interfere with a student's ability to concentrate on learning while at school.

\section{Statement of the Problem}

In Kisumu East District, guidance and counselling programme has existed in public schools since 1978 in form of career and behavioural guidance and was later strengthened to manage bullying behaviour and other indiscipline cases after the ban of corporal punishment in 2001. Despite the existence of $\mathrm{G} \& \mathrm{C}$ programme in schools, public secondary schools in Kisumu East District are still experiencing bullying problems among students such as beating and verbal abuse. The trend is worrying since in 2005, studies established that bullying occurred $100 \%$ in both boys' and girls' secondary schools and $82 \%$ in mixed secondary schools (Ajowi, 2005). Reports from the district's MoE's office indicated that student bullying cases also escalated from 200 in 2006 to 900 in 2009 and 717 in 2010 . There was need therefore to establish teachers' and students' perceptions on guidance and counselling role in addressing bullying behaviour in public secondary schools in Kisumu East District, Kisumu County, Kenya.

\section{Purpose and Objectives of the Study}

The purpose of this study was to establish teachers' and students' perceptions on bullying behaviour among students in public secondary schools in Kisumu East District, Kisumu County, Kenya.

Specifically, the study attempted to:

(i) Establish Teachers' and Students' perceptions on prevalence of bullying behaviour among students.

(ii) Identify types of bullying experienced as perceived by students.

(iii) Determine forms of bullying experienced as perceived by students.

\section{Significance of the Study}

The study findings provides information that may be useful to policy-makers, Principals, Board of Managers (BOM) and teachers to take the necessary measures to address bullying as a behaviour problem in schools that disrupt learning hence affect academic performance. Guidance and counselling programme may also be strengthened to complement the existing disciplinary methods used to manage bullying hence instill proper discipline in schools. The findings may further add to the available body of knowledge on the management of students' bullying behaviour in institutions.

\section{Methodology of Research}

\subsection{Research Design}

A descriptive survey design was used in this study to investigate the current situation with regard to the teachers and students perceptions on the bullying prevalence among students. Ngau and Kumsa (2004), describe descriptive survey design as a form of design that presents existing conditions, practices, beliefs, attitudes or opinions held, processes going on and trends for developing interpretation of meaning.

\subsection{Study Population}

The study population comprised of 47 deputy headteachers, 47 heads of guidance and counselling departments and 
7,860 form one and two students from 47 public secondary schools in Kisumu East District.

\subsection{Sample Size and Sampling Techniques}

The district had 15, 719 students in 47 public secondary schools. Stratified sampling based on school type was used to select 7,860 Form I and II students spread in 47 schools in which 37 were mixed, 5 were pure boys' and 5 pure were girls' schools. The technique ensured satisfactory representation of the three categories of schools in the study.

Simple random sampling method was used to select 12 mixed schools, 2 boys' schools and 2 girls' schools from each stratum which was about $30 \%$ of the target population making a total of 16 schools (Mugenda \& Mugenda, 2008). Saturated sampling was used to select 16 deputy headteachers and 16 heads of $G \&$ C department from the 16 selected schools. A sample size of 447 students was used in the study as generated by the Creative Research system's formula. The formular has been used by a number of researchers such as Omondi, Walingo, Mbagaya and Othuon (2010). The sample size was determined as follows: $S S=\left\{Z 2^{*}(P)^{\star}(1-P)\right\} \div C 2$, where SS=Sample size; $Z=1.96$ (for $95 \%$ Confidence level); $\mathrm{P}=0.5$ (percentage for picking needed sample/ choice); $\mathrm{C}=0.045$ (Confidence interval). Table 1 summarizes population of respondents and sample size. Proportionate sampling was therefore used to select 351 students from mixed schools, 48 from boys' schools and 48 from girls' schools respectively.

Table 1: Study Population and Sample Size

\begin{tabular}{lccc}
\hline \multicolumn{1}{c}{ Respondents } & Population & Sample size & Percentage \\
\hline Form 1 \& 2 Students & 7,860 & 447 & $05.69 \%$ \\
Deputy headteachers & 47 & 16 & $34.04 \%$ \\
Heads of G \& C department & 47 & 16 & $34.04 \%$ \\
\hline
\end{tabular}

Source: DEO Office, Kisumu East District, 2009

\subsection{Research Instruments}

The researcher used questionnaires with close-ended and open-ended questions to gather data from students, head of guidance and counselling and deputy head teachers. Structured interview schedule was also used to gather data from the head of guidance and counselling. This was used to supplement, validate and ascertain the responses in the questionnaires. Kothari (2004) and Ngau and Kumssa (2004) assert that questionnaire and interview schedule are the best methods of accessing valid information since they cannot create, waver or withhold information required by the researcher. The study was piloted by administering the questionnaires to six schools which were not included in the study sample.

\section{Results and Discussion}

\subsection{Prevalence of Bullying Behaviour among Students}

Students were asked if they have ever been bullied in school and 139 (31.1\%) indicated they have been bullied while 308 (68.9\%) reported otherwise. This is shown in Table 2.

Table 2: Students' response on being bullied ( $n=447)$

\begin{tabular}{cccc}
\cline { 2 - 3 } & Have you been bullied? & $f^{*}$ & $\%$ \\
\cline { 2 - 4 }$* f=$ frequency & Yes & 139 & 31.1 \\
& No & 308 & 68.9 \\
\cline { 2 - 4 } & Total & 447 & 100.0 \\
\hline
\end{tabular}

The data in Table 2 shows that bullying of students was 31.1\% prevalent though majority $(68.9 \%)$ of the students reported that they had not been bullied. According to Ndetei, et al., (2007) and Ajowi (2005), students in public secondary schools in Kenya experienced bullying of between 63 and 100 percent. However, 31.1\% prevalence is still high 
compared to, for instance Australia, where Cross, Epstein, Hearn, Slee, Shaw and Monks (2011) in their study on prevalence of being bullied in government secondary schools indicated that $27.7 \%$ of the students experienced bullying.

\subsubsection{Students' response on being bullied by Type of School}

Students' response on being bullied by type of school is shown in Figure 1.

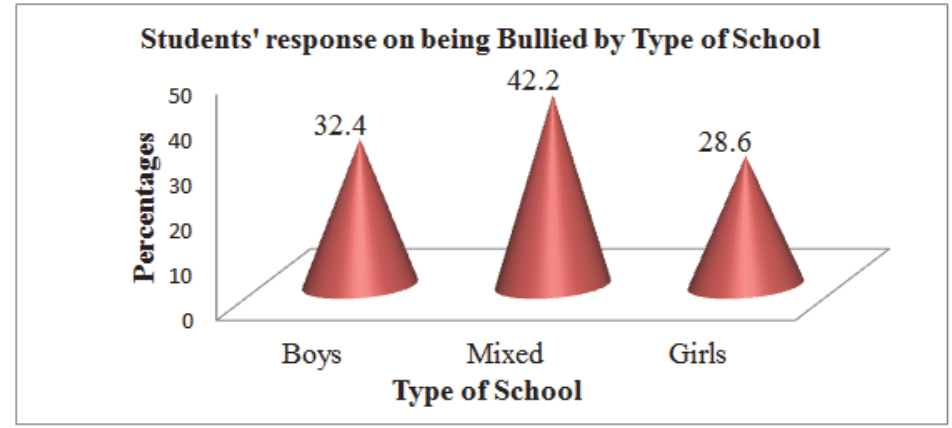

Figure 1: Students' response on being bullied by Type of School

From the data in Figure 1, bullying is most prevalent in mixed gender schools (42.2\%) followed by boys' schools (32.4\%) while it is lowest in girls' schools (28.6\%). It appears that students in mixed schools in Kisumu East District are engaging in bullying behaviour more than students in boys' and girls' schools. This is contrary to study findings by Ajowi (2005) and Simatwa (2007) though the percentage is lower but in line with study finding by Ikambili (2003). Ajowi (2005) had established that bullying of new students was higher in boys' schools (100\%) than both girls' and mixed secondary schools (82\%) respectively in Kisumu district, whereas Simatwa (2007) established that bullying of new students was $100 \%$ high in the three categories of secondary schools in Bungoma district. According to Ikambili (2003) bullying in mixed public secondary schools in Nairobi Province was high with beating of students accounting for about $30 \%$.

\subsubsection{Heads of G \& C and Deputy H/Ts' responses on Students' Bullying}

Both heads of guidance and counselling department (H.G \& C) and deputy headteachers (D.H/Ts) admitted that students were being bullied in school as shown in Table 3 .

Table 3: Students' Bullying as reported by H.G \& C and D.H/Ts

\begin{tabular}{ccc}
\hline Students bullied in school & H.G \& C $f \%$ & D.H/Ts $f \%$ \\
\hline Yes & 956.3 & 850.0 \\
No & 743.7 & 850.0 \\
Total & 16100.0 & 16100.0 \\
\hline
\end{tabular}

As indicated in Table 3, 56.3\% of heads of guidance and counselling reported that students were bullied in school while $43.7 \%$ objected. Deputy headteachers (50\%) also indicated that bullying behaviour was prevalent among students in schools but a similar response (50\%) indicated otherwise. Though more H.G \& C (56.3\%) than D.H/Ts (50\%) reported that bullying was prevalent among students in schools, the percentages confirm that bullying behaviour is indeed still a problem in public secondary schools in Kisumu East District.

\subsubsection{Students' response on Types of Bullying $(n=447)$}

When students were asked if they have observed or experienced any types of bullying in school, they responded as shown in Figure 2. 


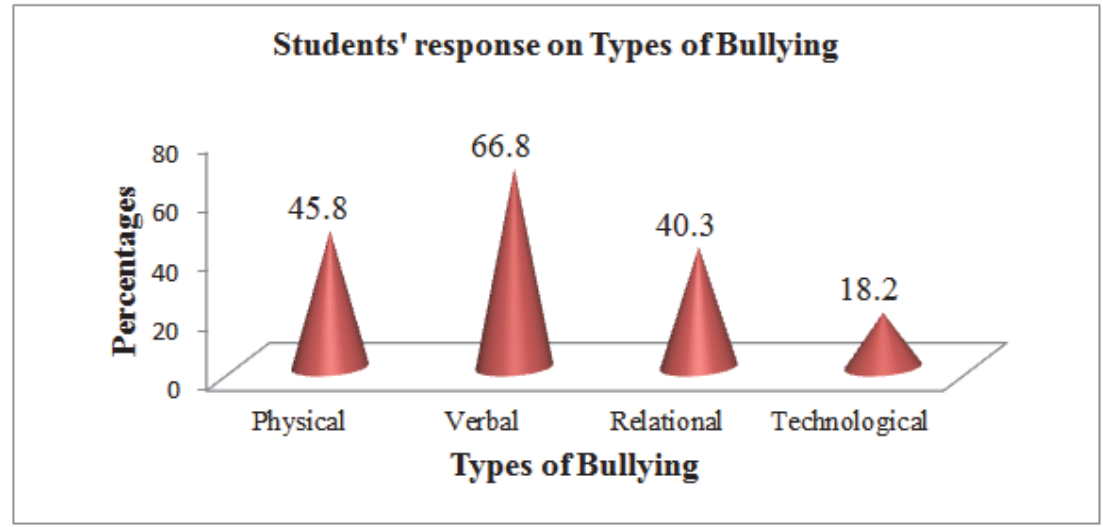

Figure 2: Students' response on Types of Bullying

From Figure 2, it emerges that verbal type of bullying was the most common bullying behaviour by $66.8 \%$ followed by physical bullying (45.8\%) and relational bullying (40.3\%). Technological or cyber type of bullying was less common. Much of literature on bullying concludes that verbal bullying seems to be a major problem since it appears to be the easiest to inflict on victims because it is quick and to the point unlike relational bullying, for instance, that takes more time to affect victims (Bohanon, et al., 2006). Additionally, it has no visible scars like physical bullying or tangible evidence such as technological / cyber type of bullying (Malematsa, 2005). In Austria, prevalence of verbal bullying was similarly found to be high (26.4\%) compared to physical bullying (12.8\%) (Spiel \& Strohmeier, 2011). Ndetei, et al., (2007) also found out in seventeen public secondary schools in Nairobi Province that $71 \%$ of the students reported having been called nasty names, $68 \%$ had tricks played on them and $64 \%$ had been blackmailed.

\subsubsection{Types of bullying as reported by Students by Type of School}

Findings of the study on types of bullying behaviour as observed by students by type of secondary school are presented in Table 4.

Table 4: Students' response on Types of Bullying by Type of School (N=447)

\begin{tabular}{lcccccc}
\hline Bullying of Students in School & \multicolumn{2}{c}{ Yes } & \multicolumn{2}{c}{ No } & \multicolumn{2}{c}{ Total } \\
Type of bullying Type of school & $\mathbf{N}$ & $\%$ & $\boldsymbol{N}$ & $\%$ & $\boldsymbol{N}$ & $\%$ \\
\hline Physical Boys & 51 & 11.4 & 51 & 11.4 & 102 & 22.8 \\
Girls & 29 & 6.5 & 36 & 8.1 & 65 & 14.6 \\
Mixed & 124 & 27.7 & 156 & 34.9 & 280 & 62.6 \\
\hline Total & $\mathbf{2 0 4}$ & $\mathbf{4 5 . 6}$ & $\mathbf{2 4 3}$ & $\mathbf{5 4 . 4}$ & 447 & 100.0 \\
\hline Verbal Boys & 74 & 16.6 & 28 & 6.3 & 102 & 22.9 \\
Girls & 51 & 11.4 & 14 & 3.1 & 65 & 14.5 \\
Mixed & 175 & 39.1 & 105 & 23.5 & 280 & 62.6 \\
\hline Total & 300 & 67.1 & 147 & 32.9 & 447 & 100.0 \\
\hline Relational Boys & 37 & 8.3 & 65 & 14.5 & 102 & 22.8 \\
Girls & 30 & 6.7 & 35 & 7.8 & 65 & 14.5 \\
Mixed & 114 & 25.5 & 166 & 37.2 & 280 & 62.7 \\
\hline Total & 181 & 40.5 & 266 & 59.5 & 447 & 100.0 \\
\hline Technological Boys & 21 & 4.7 & 81 & 18.1 & 102 & 22.8 \\
Girls & 16 & 3.6 & 49 & 11.0 & 65 & 14.6 \\
Mixed & 45 & 10.0 & 235 & 52.6 & 280 & 62.6 \\
\hline Total & $\mathbf{8 2}$ & 18.3 & 365 & 81.7 & 447 & 100.0 \\
\hline
\end{tabular}

As shown in Table 4, in boys' school, verbal bullying was the most common at $16.6 \%$ followed by physical at $11.4 \%$ then 
relational and technological. In girls' school, verbal bullying was similarly the most common at $11.4 \%$ followed by relational at $8.3 \%$ then physical and technological. In mixed school, verbal bullying was also most prevalent at $39.1 \%$ followed by physical bullying at $27.7 \%$ then relational and technological. Verbal bullying, however, still remained the most common in the three categories of schools at $67.15 \%$, followed by physical at $45.6 \%$ then relational at $40.5 \%$ and technological bullying at $18.3 \%$. This supports the argument of many scholars that it is the easiest to inflict on victims because it is quick and to the point unlike types of bullying that takes more time to affect victims. Additionally, it has no visible scars or tangible evidence like physical bullying. Indeed, in Australia, Cross et al., (2011) found out in a national bullying survey in government primary and secondary schools that $7.7 \%$ of female students engaged more in verbal bullying than male students (5.2\%) and this may account for its high prevalence in both mixed and girls' schools. However, in contrast, in Finland, Salmivalli, Karna and Poskiparta (2011) established that physical bullying was the highest among nine (9) different forms of bullying in schools though it was only $4.3 \%$ high.

\subsubsection{Types of Bullying as reported by H.G \& C}

Heads of $G \& C$ response on types of bullying among students is shown in Table 5.

Table 5: H.G \& C response on Types of Bullying

\begin{tabular}{lccccc}
\hline Do students bully others & \multicolumn{3}{c}{ Yes } & No & Total \\
\cline { 2 - 6 } by this type of bullying? & $\boldsymbol{f}$ & $\%$ & $\boldsymbol{f}$ & $\%$ & $\boldsymbol{N} \%$ \\
\hline Physical & 6 & 37.5 & 10 & 62.5 & 16100 \\
Verbal & 9 & 56.2 & 7 & 43.8 & 16100 \\
Relational & 1 & 6.2 & 15 & 93.8 & 16100 \\
Technological & 1 & 6.2 & 15 & 93.8 & 16100 \\
\hline
\end{tabular}

From the Table, $56.2 \%$ of H.G \& C indicated that verbal bullying was a major problem in schools but cases of relational and technological bullying was negligible (6.2\%). Technological bullying is less prevalent, may be because it could be an emerging type of bullying among the youth or due to banning of cell-phone use by students in schools by the government of Kenya. Reports from interview with heads of $G \& C$ on the other hand, showed that physical bullying was the most prevalent followed by verbal, relational and then technological bullying.

\subsubsection{Types of Bullying as reported by D.H/Ts}

Deputy headteachers were equally asked if students in school did physically, verbally, relationally and cyber bully other students and their response is shown in Table 6.

Table 6: D.H/Ts' response on Types of Bullying

\begin{tabular}{lccccc}
\hline Do students bully others & & Yes & No & Total \\
\cline { 2 - 6 } by this type of bullying? & $\boldsymbol{f}$ & $\%$ & $\boldsymbol{f}$ & $\%$ & $\boldsymbol{N} \%$ \\
\hline Physical & 6 & 37.5 & 10 & 62.5 & 16100 \\
Verbal & 8 & 50.0 & 8 & 50.0 & 16100 \\
Relational & 10 & 62.5 & 6 & 37.5 & 16100 \\
Technological & 0 & 0.0 & 16 & 100.0 & 16100 \\
\hline
\end{tabular}

As shown in Table 6, it emerged that all $16 \mathrm{D} . \mathrm{H} / \mathrm{Ts}(100 \%)$ indicated that technological bullying was non-existent in schools, but 10 D.H/Ts (62.5\%) reported relational bullying was most prevalent

\subsection{Forms of Physical Bullying as reported by Students ( $n=447)$}

The study surveyed forms of physical bullying and students' response was analyzed as shown in Figure 3. 


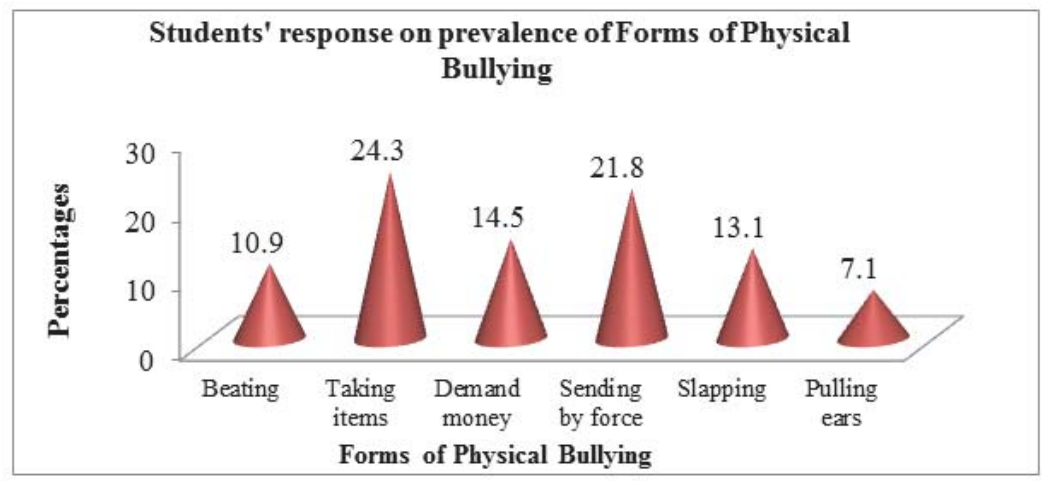

Figure 3: Students' response on Forms of Physical Bullying

From figure $3,24.3 \%$ of students indicated that taking victims personal items was the biggest challenge followed by forceful sending (21.8\%), demanding money (14.5\%), slapping (13.1\%) and beating (10.9\%). Pulling ears was least rated by 7.1\%. In Finland schools, according to Salmivalli, Karna and Poskiparta (2011), material taking from fellow students particularly money was similarly rated high though at $1.3 \%$ and ranked fourth after verbal, exclusion and physical bullying in a national anti-bullying survey. Ndetei et al. (2007) in a study on prevalence of bullying in public secondary schools in Nairobi Province additionally established that taking away of belongings was most common (82\%) especially from boarding students in Forms one and two. Recently, Daily Nation (2012) reported a similar case in a public secondary school in Kangundo, in which Form two students torched a dormitory in protest of their personal property being stolen by senior students. In-depth interview with H.G \& C further indicated that in secondary schools students also experienced pinching, kicking and taking food from victims as forms of physical bullying.

\subsection{Forms of Verbal Bullying as reported by Students $(n=264)$}

The study further set to find out forms of verbal bullying in schools is shown in Figure 4.

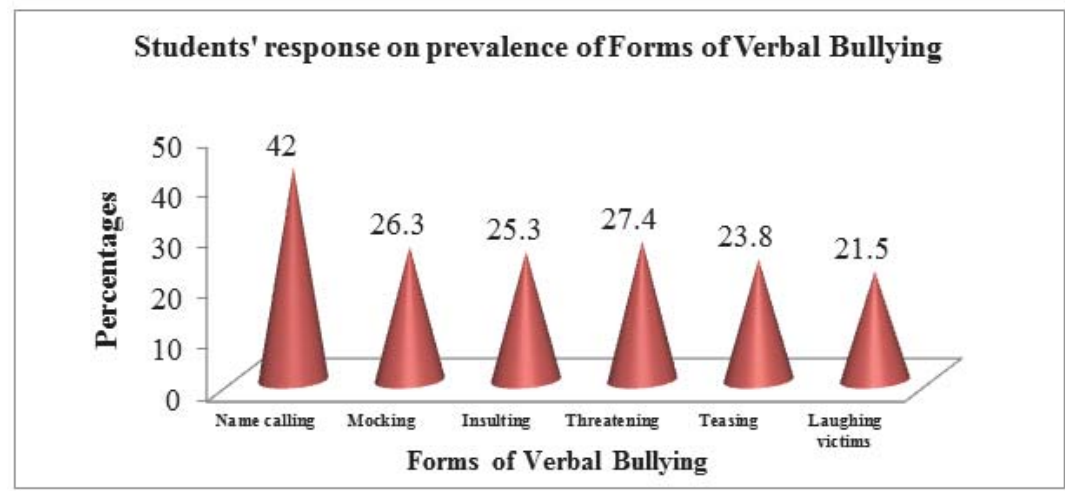

Figure 4: Students' response on Forms of Verbal Bullying

As shown in Figure 4, 42 percent of students identified name calling as the most common form of verbal bullying followed by threatening (27.4\%), mocking (26.3\%) and insulting (25.3\%). Laughing at victims and teasing as forms of bullying were reported by only $21.5 \%$ and $23.8 \%$ of the respondents respectively. From the study, it appears name calling (42\%) is therefore a major challenge as a form of verbal bullying in schools than insulting, mocking, threatening victims, teasing and laughing at victims. This is in line with study findings by Onditi (2007) who established that pupils in primary schools in Suneka division, Kisii district rated name-calling by teachers at $62.4 \%$. This problem affected more girls than boys and contributed to school dropout. 


\subsection{Forms of Relational Bullying as reported by Students ( $n=159)$}

Students' response from the survey identified gossiping, ignoring victims, humiliating victims, group isolation, spreading rumors and hiding belongings as forms of relational bullying. This is shown in Figure 5.

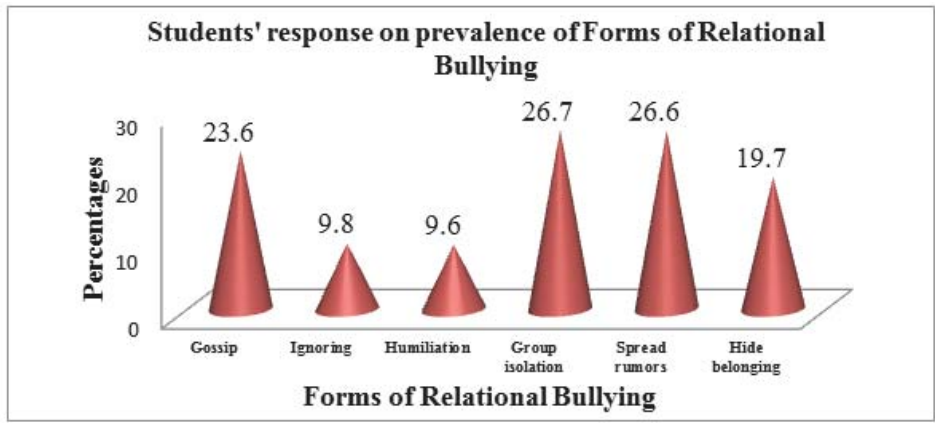

Figure 5: Student's response on Forms of Relational Bullying

As shown in Figure 5, 26.7\% of students identified group isolation as the main relational problem in public secondary schools followed by spreading rumours (26.6\%) and gossip (23.6\%). Few students (9.8\%), however, indicated ignoring colleagues and humiliation of bullying victims (9.6\%) were common. The high prevalence of group isolation (26.7\%), spreading rumours (26.6\%) and gossip (23.6\%) as forms of relational bullying nearly concurs with Hazemba, et al. (2008) who reported in a sample of 692 Turkish high school students, that $28.3 \%$ indicated having been bullied emotionally, at least once during an academic year. The percentage of group isolation (26.7\%) is also higher than findings of Salmivalli, Karna and Poskiparta (2011) in a study to find out the effectiveness of a national anti-bullying program (Ki-Vi) in Finland government schools, which established that exclusion of students or group isolation was rated $5.3 \%$ by students.

Though gossip $(23.6 \%)$ is still a relational problem in public secondary schools in Kisumu East district, its percentage is lower than that of schools in Western Province in Kenya where $73.5 \%$ of students reported gossiping as a major factor contributing to violent behaviour as established by Poipoi, Agak and Kabuka (2011). According to Low, Frey \& Brockman (2010) relational type of aggression is rated by children to be more painful than even physical aggression although in Florida, USA, the second annual bullying prevention conference in April, 2007, observed that just as males were more likely to use physical and verbal aggression than females, the latter were also better than males in relational bullying (Batsche, 2007).

\subsection{Forms of Technological Bullying as reported by Students ( $n=72)$}

Students further identified use of visual messages, audio-messages, audio-visual and written (SMS) messages as forms of cyber / technological bullying as shown in Figure 6.

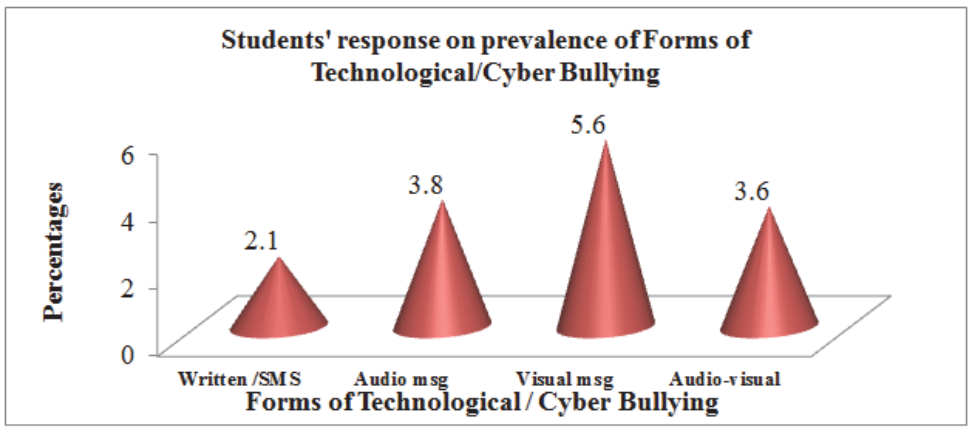

Figure 6: Students' response on Forms of Technological / Cyber Bullying

From the Figure, use of visual messages (5.6\%) is the most prevalent form of technological / cyber bullying but use of 
written messages through internet or SMS via cell-phones (2.1\%) was the least common form of bullying victims. Cyber bullying, Thomas \& McGee (2012) argue, is more pervasive and harmful than other types of bullying such as physical bullying. This is because its effects can reach a large number of victims at once and the bully also doesn't have to be physically present. However, prevalence of these forms of cyber bullying is generally low (below 6\%) compared to a recent study by the Pew Internet and American Life Project which established that $26 \%$ of teens have been harassed through their mobile phones either by calls (audio) or text messages (SMS) (Lenhart et al., 2010 in Thomas \& McGee (2012). In Brisbane, Australia, Campbell (2005) also reported a higher percentage of cyber bullying where $11 \%$ of students identified themselves as cyber bullies and nearly $14 \%$ as victims. Ndetei et al. (2007) argue that since girls value social relationships more than boys those who are bullies hence set out to disrupt social relationships of the girls they bully by telling lies or spreading rumours about them using new technologies such as cell-phones. In Kenya, MoE banned possession and use of mobile phones in public schools since they were blamed for spreading rumours that spread damage in schools during rampant unrests (Opondo, 2008)

\section{Conclusions}

\subsection{Prevalence of Bullying}

Findings of the study revealed that bullying of students was still prevalent in public secondary schools in Kisumu East district. By type of school, bullying was most prevalent in mixed gender schools but least prevalent in girls' schools.

\subsection{Types of Bullying}

The study revealed that out of the physical, verbal, relational and technological / cyber types of bullying, verbal type of bullying was the most common. By type of school, verbal type of bullying was still the most common in all the three categories of schools.

\subsection{Forms of Bullying}

Concerning forms of physical bullying, taking victims personal items was the most common, while name calling was concluded as the major problem of verbal bullying. Group isolation and spreading rumours were the worst forms of relational bullying whereas use of visual messages / pictures was concluded as the most common forms of technological bullying.

\section{Recommendations}

1. Schools should adopt a whole-school anti-bullying approach for prevention and interventions.

2. National prevention and intervention programmes should focus on verbal and the emerging and escalating technological / cyber types of bullying.

\section{References}

Ahmed, E. (2005). Pastoral Care to Regulate School Bullying: Shame Management among Bystanders. Pastoral Care in Education, 23 (2): 23-29. Aluede, O. (2011). Managing Bullying problem in Nigerian Secondary Schools: Some Counselling Interventions for Implimentation. The African Symposium, African Educational Research Network, 11 (1): 138-145.

AMA Alliance, (2007). Facts from the Alliance of Childhood Bullies and Victims. [Online]. Available http://www.amaalliance.org/ Childhood_Bullies_and_Victims.pdf (October 11, 2008).

Anonymous, (2003). Bullying: 'Some causes and effects.' Awake, 84 (16): 5-7.

Batsche, G. M. (2007, April 17). Bullies and their Victims: Understanding a pervasive Problem in schools. Available from (Florida's $2^{\text {nd }}$ Annual Bully Prevention Conference). [Online]. Available http://sss.usf.edu/resources/Presentations/2007/ bullyconference batsch.ppt.html (October 11, 2008).

Beran, T. \& Li, Q. (2007). The Relationship between Cyber and School Bullying. Journal of Student Wellbeing, 1 (2): 15, 33.

Bohanon, H., Fenning, P., Carney, K., Minnis-kim, M., Anderson-Harriss, S., Moroz, K.B., Hicks, K. J., Kasper, B.B., Culos, C., Sailor, W. \& Pigsott, T.D. (2006). School-wide Application of Positive Behaviour support in an Urban High School: A Case Study.

Journal of Positive Behaviour Interventions. [Online].Available http://www.accessmylibrary.com/com2/browse_JJ_J027. (October 11, 2008). Campbell, M.A. (2005). Cyber Bullying: An Old problem in a new guise? Australian Journal of Guidance and Counseling, 15 (1): 68-76. 
Creative Research System, (2003). The Survey system: Sample size calculator. [Online]. Available http://www.surveysystem.com/sscale.htm. (August 11, 2009).

Cross, D., Epstein, M., Hearn, L., Slee, P., Shaw, T. \& Monks, H. (2011). National Safe Schools Framework: Policy and Practice to reduce bullying in Australian schools. International Journal of Behavioural Development, 35 (5): 398-404.

Daily Nation, (2012, July 23rd). "Students set dorm a blaze after clash". Nairobi: NMG p.6.

Daphine II Programme, (2008). International State-of-the Art Survey 2006-2007. Bullying at School and Play at School-Fair Play in Society. [Online]. Available http://www.opeko.fi/english/document/stateoftheart.doc. (October 11, 2008).

D.E.O, (2009). Kisumu District Education Office. Kisumu: Statistics Department.

Eisenberg, M., Neumark-Sztainer, D., \& Percy, C. (2003). Peer harassment, school connectedness, and academic achievement. Journal of School Health, 73, 311-316.

Gichana, A.,Obiero, D., Nyarora, H. \& Oloo, E. (2008, June 18). 'Students Riots to be probed, says Ongeri.' Daily Nation, p.37.

Grinnell Jr., R.M.(2001). Social Work Research and Evaluation (6th ed). Illinois: F. E. Peacock publishers.

Hayes, D. (2008). 'Ban mobile phones to curb bullying'. [Online].Available http://www.thisislondon.co.uk/standard/article (January16, 2009).

Hazemba, A., Siziya, S., Muula, S.A. \& Rudatsikira, E.(2008). Prevalence and Correlates of being bullied among in-school adolescents in Beijing: Results from the 2003 Beijing Global School-based health survey. Ann Gen Psychriatry, 7(6). [Online]. Available http://www.pudmedcentral.nihi.gov/redirect3.cgi?/html (February 20, 2009).

Jacobsen, K.E.\& Bauman, S. (2007). Bullying in Schools: School Counselors' Response

to Three Types of Bullying Incidents. Professional School Counseling, October, 2007. [Online]. Available http://www.accessmylibrary .com/com2/summery_0286-3387013_ITM. (September 19, 2008).

Jones, N., Moore, K., Villar-Marquez, E. \& Broadbent, E. (2008, October). 'Painful Lessons: The Politics of Preventing Sexual Violence and Bullying at School-Working Paper 295.' London: Overseas Development Institute and Plan International. (online).

Kandagor, J. (2008). The Monster that "Monolization" has now become. In, Education Insight, April-May 2008, 15 (17).

Kiplagat, R. (2013, Thursday, June 20th). Bullies force Form One Student to Drink Ethanol. East African Standard, Nairobi: SMG, p. 26.

Kiplagat, S. (2008, Thursday, Feb.14th). 'Bullying, a reality headteachers dread talking about'. Daily Nation, Nairobi: NMG, p. 3.

Kothari, C.R. (2004). Research Methodology: Methods and Techniques. New Delhi: New Age International Publishers.

Lopes Neto, A.A. (2005). Bullying-Aggressive Behaviour Among Students. J. Pediatr. (Rio J.) Vol. 81 No. 5 Suppl. O Porto Alegre Nov. 2005.

Low, S.,Frey, K.S. \& Brockman, C.J. (2010). Gossip on the Playground: Changes Associated With Universal Intervention, Retaliation Beliefs, and Supportive Friends. School Psychology Review, 39 (4): 536-551.

MacNeil, G. (2004) School Bullying: Who, Why, and What to Do. In, The Preventive Researcher,11 (3):15-17. [Online]. Available http://www.tproline.org/issue.cfm/Juvenile_Bullying (October 26, 2008).

Malematsa, M.M. (2005). A Case Study on Bullying in a Secondary School in Atteridgeville, South Africa. [Online]. Available http://Oetd.uj..ac.za.ujlink.uj.ac.za/theses/available/etd-10182005-1128061html (March 9, 2008).

Mathui, M. (2008, July 26 $6^{\text {th }}$. No party is innocent in school fires tragedy. Daily Nation, Nairobi: NMG, p. 3.

Ministry of Education Science and Technology (MOEST) (2000/2001). Report on Causes, Effects, and Remedies of Indiscipline in Secondary Schools in Central Province. Nairobi: Government printers.

Moessner, C. (2007). Cyber bullying. Trends and Tunes. Vol. 6 (4). Retrieved 2010, June 21 from http/l:www.harrisinteractive.com Inews/newsletter/k12news/HI_TrendsTudes_2007_v06_04.pdf

Moris, D. (2012). Bullying among secondary school students in Dar-es-Salaam region. Papers in Education and Development, Vol 28: 40-60.

Morrison, B.E. (2002). Bullying and Victimization in Schools: A Restorative Justice Approach. Available from Australian Institute of Criminology: Trends and Issues Series, No. 219 February.

Moswela, B. (2005). Peer victimization in schools: Response from Botswana. Journal of Social Sciences Special Issue, 8, 29-35.

Mugenda, M. O. \& Mugenda, A. G. (2008). Research method: Qualitative and Quantitative Approaches. Nairobi: Acts Press.

Mutie, E.K. \& Ndambuki, P. (2001). Guidance and Counselling for Schools and Colleges. Nairobi: Oxford University Press.

Mwangi, M. (2008, Thurs., Feb.14th). 'The Day School's Annual Ritual Turned Tragic.' Daily Nation, Nairobi: NMG, p. 3.

Ndetei, D.M., Ongecha F.A., Khasakhala L., Syanda J., Mutiso V., Othieno C.J.,

Odhiambo G., \& Kokonya D.A.(2007). Bullying in Public Secondary Schools in Nairobi, Kenya. Journal of Child and Adolescent Mental Health, 19 (1): 45-55.

Mwajefa, M. \& Marete, G. (2008, Fri., June 27th). 'Stick to ethics, Principals told'. Daily Nation, Nairobi: NMG, p. 5

Ndibalema, P. (2013). Perceptions about bullying behaviour in secondary schools in Tanzania. The case of Dodoma Municipality. International Journal of Education and Research, Vol. 1 (5):1-16.

Nelson, M. (2003). 'School bullies going high-tech'.[Online].Available http://www.canoe.ca/NewsStand/London.FreePress? Nnews/2003/03/02/174030.html (March 21, 2009).

Ngau, P. \& Kumssa, A.(Eds) (2004). Research Design, Data Collection and Analysis: A Training Manual. United National Centre for Regional Development Africa office.

Nyasato, R. (2009, March 18th). "Nyambaria Boys expels six Form-four bullies". E.A Standard. Nairobi: SMG p. 26.

Okwemba, A. (2007, May 17th). 'Kenyan Students are Top Bullies'. Daily Nation, HORIZONS. Nairobi: NMG, p.15.

Oliver, C. \& Candappa, M. (2003). Tackling bullying: Listening to the views of children and young people. Norwich: Queen's Printer.

Olweus, D. (1993). Bullying in schools: What we know and what we can do. Oxford: Blackwell.

Omondi, D. O., Walingo, M.K., Mbagaya, G. M. \& Othuon, L.A.O. (2010). Predicting dietary practice behaviour among Type 2 diabetics using the theory of planned behaviour and mixed methods design. International Journal of Medicine and Medical Sciences, 1 (2): 117-125. 
Opondo, O. (2008, July 23rd). 'Tough new rules to curb school strikes'. Daily Nation. Nairobi: NMG, p. 1, 4.

Ouma, M. A., Simatwa, E. M. W. \& Serem, T.D.K. (2013). Management of pupil discipline in Kenya: A case study of Kisumu Municipality. International Research Journal, 4 (5), 374-386.

Patchin, J. N. \& Hinduja, S. (2009). Bullies move beyond the School yard. A preliminary look at Cyber Bullying. Youth Violence and Juvenile Justice, 4 (2): 148-169.

Poipoi, M.W., Agak, J.O. \& Kabuka, E.K. (2011). Perceived Home Factors contributing to Violent Behaviour among Public Secondary School Students in Western Province, Kenya. Journal of Emerging Trends in Educational Research and Policy Studies, 2 (1): 30-40.

Republic of Kenya, (2002). "Policy framework for Guidance and Counselling in Education". Draft Document. Prepared for a workshop at KIE by MoEST $9^{\text {th }}-10^{\text {th }}$ April.

Republic of Kenya (2001b). Report of the Task Force on Student Discipline and Unrest in Secondary Schools. Nairobi: Government Printer.

Saito, M. (2011). Violence in primary schools in Southern and Easter Africa. Evidence from SACMEG. International Institute for Educational Planning (IIEP): Nairobi.

Salmivalli, C., Karna, A. \& Poskiparta E. (2011). Counteracting Bullying in Finland: The KiVa Program and its effects on different forms of being bullied. International Journal of Behavioural Development 35 (5) 405-411.

Shariff, S. (2008). Cyber-Bullying: Issue and Solutions for the School, the Classroom and the Home. Canada: Routledge.

Spiel, C. \& Strohmeier, D. (2011). National Strategy for Violence Prevention in the Australian Public School System: Development and Implementation. International Journal of Behavioural Development 35 (5): 412-418.

Smith, P. K. (2011). Why Interventions to Reduce Bullying and Violence in Schools may or may not succeed. International Journal of Behavioural Development, 35 (5): 419-423.

Thomas, K.M. \& McGee, C.D. (2012). The Only thing We Have to Fear is 120 Characters. TechTrends, 56 (1): 19-33.

Who, (2004). GSHS Country Report on the Philippines. [Online].Available http://www.who.int/chp/gshs/2004\%20GSHS\%20 PHL\%20Final\%20Report.pdf (October 11, 2008). 